\title{
Management for traumatic neuropathy after dental treatment
}

\author{
Sung-Hee Jeong ${ }^{1,2}$, Sunhee Lee ${ }^{1,2}$, Yong-Woo Ahn", ${ }^{1,2}$ Jun-Young Heo ${ }^{2}$, Hye-Mi Jeon ${ }^{3}$, Soo-Min Ok ${ }^{1,2 *}$ \\ ${ }^{1}$ Department of Oral Medicine, School of Dentistry, Pusan National University, Dental Research Institute, Yangsan, Republic of Korea \\ ${ }^{2}$ Department of Oral Medicine, Pusan National University Dental Hospital, Dental Research Institute, Yangsan, Republic of Korea \\ ${ }^{3}$ Department of Oral Medicine, Pusan National University Hospital, Busan, Republic of Korea
}

Whereas a somatic pain notifies tissue damage, a neuropathic pain presents disorder of the nerve itself. The causes of neuropathic pains are trauma, infection, chronic irritation by adjacent tissue and so on. The iatrogenic trauma or infection also causes traumatic neuropathy, which may exert a bad influence on doctor-patient relationship. Some of related dental treatments are implantation (directly or indirectly through heating), root canal treatment, teeth extraction, block anesthesia, mandibular surgery. If inappropriate management is performed after nerve trauma, there will be many chances to develop chronic neuropathy for the patient. It is important that the sign of nerve trauma have to be caught by the practitioner as soon as possible and treated properly. (J Dent Rehabil Appl Sci 2016;32(2):123-9)

Key words: traumatic neuropathy; latrogenic trauma

\begin{abstract}
서론
통증이란 실제적인 또는 잠재적인 조직의 손상과 연 관되어서 느껴지는 불유쾌한 감각이나 정신적인 경험 으로 정의한다. ${ }^{1}$ 통증의 주된 기능은 과도한 물리적 또 는 화학적 자극으로 인한 손상으로부터 신체를 보호하 기 위한 것이며 불유쾌한 감각이나 감정적 경험도 포함 하는 것임을 의미한다. 조직손상 시 통증, 감각 등을 느 끼는 신경도 다양한 환경 및 다양한 자극에 의해 손상 이 생길 수 있다. 신경은 손상 시 재생이 느리고 회복에 실패하는 경우도 많다. ${ }^{2,3}$ 이러한 신경손상에 의한 결과 는 양성감각증상(positive sensory symptom)과 음성감 각증상(negative sensory symptom)으로 나타날 수 있다. 외과적 시술 후 나타나는 감각상실(aesthesia), 감각저하 (hypoesthesia), 통각감퇴(hypoalgesia)는 음성감각증상 에 속하고, 평소에는 특기할 불편이 없으나 접촉 혹은
\end{abstract}

*Correspondence to: Soo-Min Ok

Assistant Professor, Department of Oral Medicine Pusan National University Dental Hospital, Dental Research Institute, 20, Geumo-ro, Mulgeum-eup, Yangsan, 50612, Republic of Korea

Tel: +82-55-360-5243, Fax: +82-55-360-5238, E-mail: oksoomin@pusan.ac.kr

Received: April 28, 2016/Last Revision: June 10, 2016/Accepted: June 13, 2016
자극시 감각에 이상을 느끼는 이상감각(paresthesia), 불 쾌한 이상감각(dysesthesia), 이질통(allodynia), 통각과민 (hyperalgesia: 통각에 예민함, hyperpathia: 특히 반복적 자극에 대해 통각을 크게 느끼는 증후군) 등은 양성감각 증상에 속한다.

이러한 신경병변성 통증은 환자로 하여금 말하기, 먹 기, 키스하기 등 일상생활을 모두 어렵게 하는 심각한, 삶의 질을 저하시키는 질병이다. ${ }^{4}$ 이러한 손상의 의원성 특성은 부정적 심리효과(negative psychological effects) 를 악화시킨다. ${ }^{5}$ 외과적 시술 후는 신경손상 가능성에 대한 신속한 평가와 처치를 통해 환자의 신경병변성 통 증의 가능성과 정도를 줄여 줄 수 있으며 외과적 시술 전 위험요소 고려를 통한 예방이 더 중요하다.

치과시술시 병인요소는 술중과 술후로 나뉠 수 있다. 손상 기전에 따라 술중 병인요소는 기계적(mechanical), 열적(thermal), 화학적(chemical) 요소로 나뉠 수 있고,

Copyright@ 2016 The Korean Academy of Stomatognathic Function and Occlusion. (c) This is an Open-Access article distributed under the terms of the Creative Commons Attribution Non-Commercial License (http://creativecommons.org/ licenses/by-nc/4.0) which permits unrestricted non-commercial use, distribution, and reproduction in any medium, provided the original work is properly cited. 
술후 간접적 병인요소로 열, 감염, 허혈과 반흔을 동 반하는 혈종으로 나뉠 수 있다. 이전에는 신경이 절단 되면 단순히 통증이 사라질 것으로 생각되었으나 실 제로 물리적, 화학적, 혹은 열적 손상으로 구심로차단 (deafferentation)이 일어나면 오히려 새로운 통증을 유 발할 수도 있음이 밝혀져 있다. 기계적 인자는 마취 바 늘, 임플란트 드릴, 임플란트, 골파편, 혈종, 수술용 칼, 연조직 견인 기구 등이다. 이들에 의해 직접적인 신경의 압박(pressure), 침해(encroach), 단절(transaction), 열상 (laceration) 등이 발생할 수 있으며, 또한 직접적인 손상 이후 발생하는 혈종, 허혈과 압박에 의한 간접적인 신경 의 손상이 발생할 수 있다.

치과치료 중 화학적 열적 손상은 직접적인 신경구조 파괴를 야기할 수 있다. 술후 열, 감염 등의 간접적 병인 은 이후 신경 구조의 변성을 일으키는 염증, 이차적 허 혈을 야기할 수 있다. 혈종은 조직의 반흔을 야기하고 신경혈관 다발(neurovascular bundle)의 이차적 허혈은 신경변성을 야기한다.

환자의 외과적 시술 후에는 항상 마취가 풀린 직후 지 각이상 여부에 대한 경과 관찰이 필요하고 지각이상이 일어났을 때 제일 먼저 부위를 확인하고 양상을 체크한 다. 적절한 검사 후 증상에 따라 약물치료, 심리적 지지, 추가적인 물리치료 등이 필요할 수 있으며 시술 3개월 후 재 평가를 통해 수술적 접근의 필요성에 대한 검토가 필요하다.

임플란트, 발치, 신경치료 등의 외과적 치과치료 후 지 각이상으로 고생하는 환자들이 점점 증가하고 있다. ${ }^{6,7}$ 이의 법적인 대응도 향후 증가할 수 있다. ${ }^{7}$ 하지만 아직 치과의사들은 치과 시술 후 나타날 수 있는 지각이상에 대해 정확한 개념이나 처치에 대한 지식이 부족한 실정 이다. 본 연구에서는 치과시술 후 지각이상이 나타난 세 증례 분석을 통해 치과 시술 시 지각이상의 위험군을 판 단하고, 시술시의 위험성을 감소시키고 지각이상 발생 시 적절한 처치를 통하여 손상을 최소화하여 관리하는 방법에 대하여 고찰해 보고자 한다.

\section{증례 보고}

\section{1. 증례 1}

특별한 의과적 병력이 없는 50대 남성으로 \#45i, 46i, $47 \mathrm{i}$ (임플란트)를 식립 하였고 4개월 후 실패하여 \#45,
$46,47 \mathrm{i}$ 제거 후 재식립 하였다. 이후 마취가 안 풀리는 느낌이 들고 아래 입술 부위의 우리함을 호소하였다. 5 일 후 \#45i 제거(mechanical decompression은 36시간 이내가 이상적 ${ }^{4}$ 하였고, 또 6 일이 지난 후 구강내과에 초 진 내원하였다(Fig. 1).

전류인지자극역치검사 결과 우측 하악신경 부위의 유 의한 감각저하 소견을 보였다. DCT (dental computed tomography)결과 \#45i는 이공상방에 식립 되었다가 발거된 것으로 추측되며 \#46i, 47i는 하악관 상방에 식 립 되어 있었다(Fig. 2). 신경 주변의 염증, 부종반응으 로 인한 추가적인 손상을 최소화하기 위해 prednisolon tapering을 시행하였고, 추가적인 통증(환자의 지각이 상의 양상에 따라 과민화되어 있는 신경에 대한 진정 을 위해 각종 항경련제 등의 neuroleptic agent를 쓴다) 조절을 위해 gabapentin과 amitriptyline을 투약하였고 rehabilitation을 위해 물리치료(low level laser therapy: biolaser)를 적용했다. NRS (numerical rating scale)가 초 진 내원 당시의 9에서 9개월 후 2 - 3으로 감소하였고 추 가적인 전류인지자극요법 검사 상으로 이상소견이 관찰 되지 않았다. 향후 임플란트 식립을 계획하고 있으며 지 속적인 biolaser 시행 중이다.

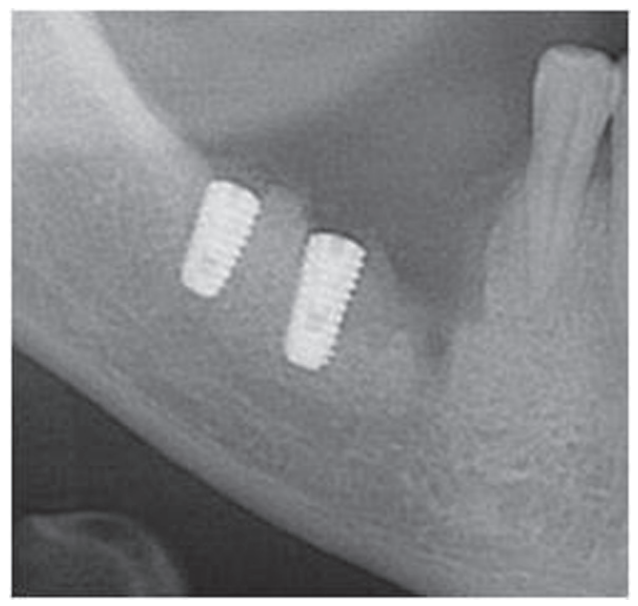

Fig. 1. The related part of the panoramic view of the 1st case, which shows \#47i, 46i and recently extracted \#45i site. 

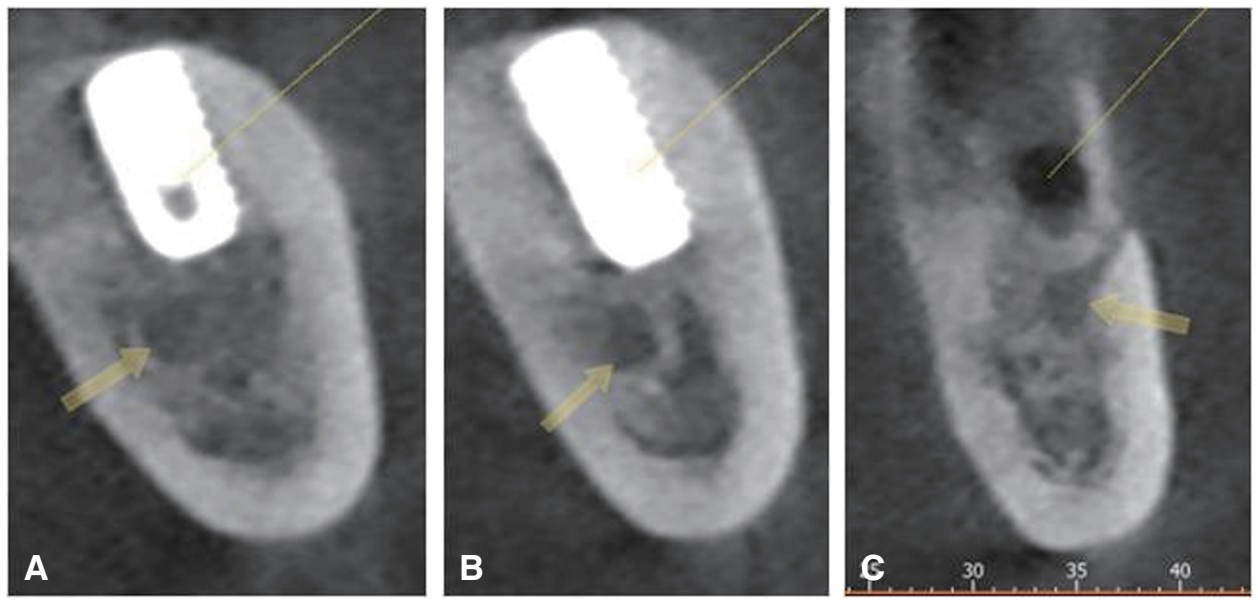

Fig. 2. Dental CBCT coronal views of \#47i (A), \#46i (B), \#45i extraction site (C). The arrows are pointing the mandibular canal.

\section{2. 증례 2}

의과병력 없는 50 대 남자로 \#38발치 후 혀 왼쪽 부 위 마취가 안 풀린 듯 얼얼하고 화끈거리는 통증을 주소 로 내원하였으며 내원시 치과에서 처방한 약물(성분 미 상)을 2주간 복용하였으나 호전이 없었다고 하였다. 발 치 후 15일째 되는 날 초진 내원하였다(Fig. 3). 신경 주 변의 염증, 부종반응으로 인한 추가적인 손상을 최소화 하기 위해 prednisolon tapering을 시행하였고, 추가적인 통증조절을 위해 gabapentin과 amitriptyline을 투약하였 고 rehabilitation을 위해 biolaser를 적용했다. 또한 신경 의 추가적인 자극을 줄이기 위해 혀물기 등의 습관을 제 한하도록 교육하였다. 2 개월 후 NRS는 5 에서 0 으로 감 소하였고 범위 또한 줄어들었다(Fig. 4).
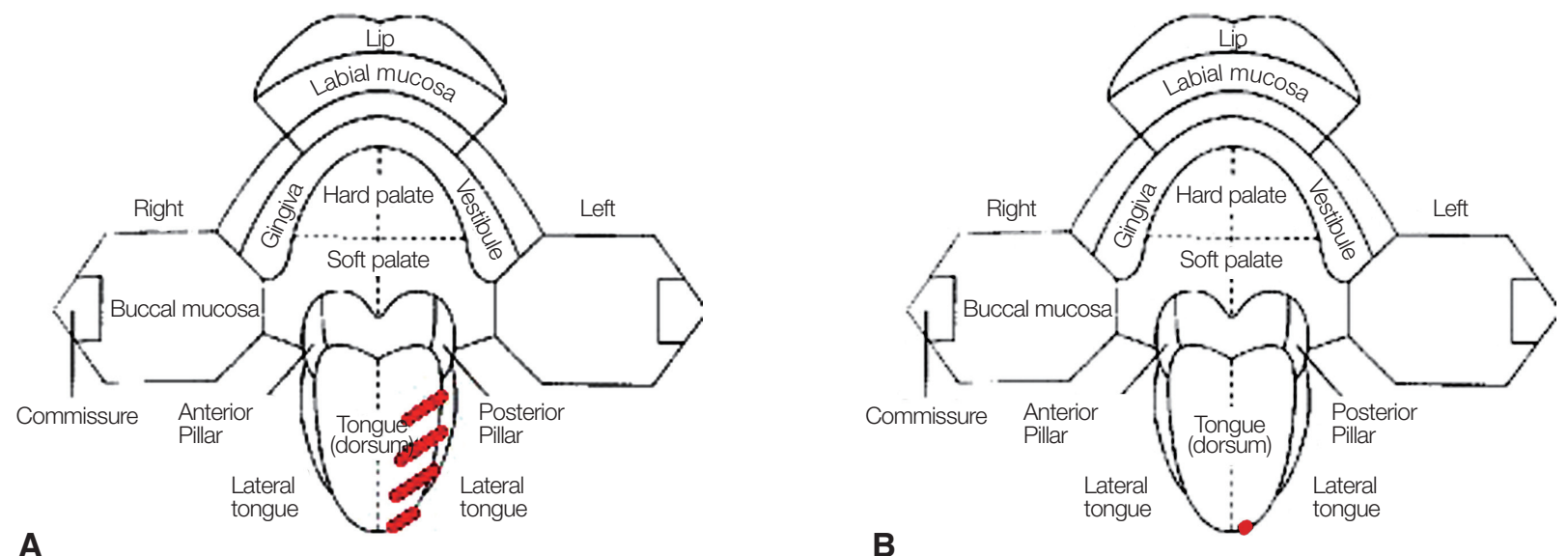

Fig. 4. Drawings of the paresthetic areas from the clinical chart of the 1st visit (A) and after 2 months (B). 


\section{3. 증례 3}

43세 남자환자로 2년 전 하악 전악 임플란트 식립을 하였고 이후 우측 턱에 hypoesthesia, sharp pain이 존재 하였는데 방치하다가 1 년 뒤부터 약을 복용하였으나 구 토, 어지러움 등으로 중단하였다. 증상이 점점 심해져서 현재 우울증 치료중인 상태로 구강내과에 초진 내원하 였다(Fig. 5). 초진시 주소는 '통증 때문에 발음, 저작이 힘들고 침이 흐른다' 는 것이었다. 임상검사 결과 우측 V3 division의 allodynia와 hypoesthesia가 혼재된 증상 을 보였고 DCT상 우측 임플란트(\#47i, 46i, 44i) 모두 하 악관 상연과 떨어져 식립 되어 있었다(Fig. 6). 우울증약 복용중이었으므로 추가적인 약 처방시 부작용의 우려가 커 복용약 없이 biolaser만 처방하였다. 1개월 반 동안 8 회 내원하였는데 차도가 없었고, 후유장애진단서를 발 급하고 치료종결 하였다.

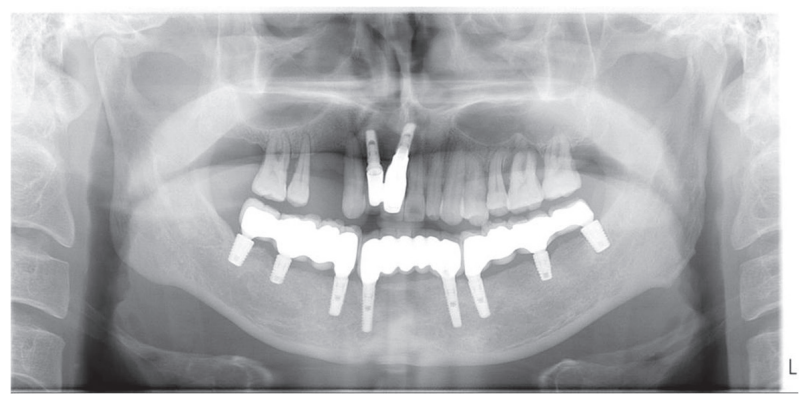

Fig. 5. A panoramic view of the 3rd case which shows implantations on all over the lower alveolar ridge.

\section{고찰}

증례 1에서 \#45, 46, 47i 모두 하악관과 이공상방에 식 립되어 있음을 확인할 수 있었고 시술시 하악관이나 이 공을 침범한 흔적을 찾을 수는 없었다. 하지만 그럼에도 불구하고 환자는 지각이상을 호소하였다. 이 경우 신경 손상이 직접적인 열자극 외에 임플란트 당시 생길 수 있 는 열자극이나 화학적 자극(마취액이나 오염된 식염수 등)에 의해서, 혹은 직접적 침범 없이 간접적으로 가해 지는 압력(침범하지는 않았지만 가까이 식립되어 신경 관에 압력, 또는 하악관이나 이공내의 혈종, 부종에 의 한 압력) 등에 의해 신경의 손상, 이상감각이 야기되었 을 것으로 생각된다. 스테로이드의 빠른 적용으로 신경 주변의 부종, 염증을 줄이고 신경막을 안정화하여 심한 지각이상을 예방하고 증상을 완화시킬 수 있었다. ${ }^{8}$

증례 2는 하악전달마취 시 설신경에 손상이 생겼을 것 으로 추정되는 환자다. 설신경 손상은 염증이나 출혈이 발생시 해부학적 조건으로 빠져나갈 수 없어 압박으로 인한 신경 손상이 생기기 쉬운 하악관에 비해, 신경이 완전 절단되지 않았을 경우, 부종과 출혈에 대한 손상이 덜하고 회복이 빠를 수 있다. 역시 빠른 처치가 예후를 좋게 한 것으로 사료된다.

증례 3은 손상직후 처치 및 심리적 지지도 없이 방치 되어 우울증까지 발생한 환자로 손상 직후 관리가 제대 로 이뤄졌다면 환자의 불편감이 훨씬 감소되고 소송까 지 가지도 않았을 가능성이 크다. 통증은 지속 시 중추 신경의 변화를 유도하여 더 잘 낫지 않는 형태로 진행되 기에 초기 관리가 중요하다.
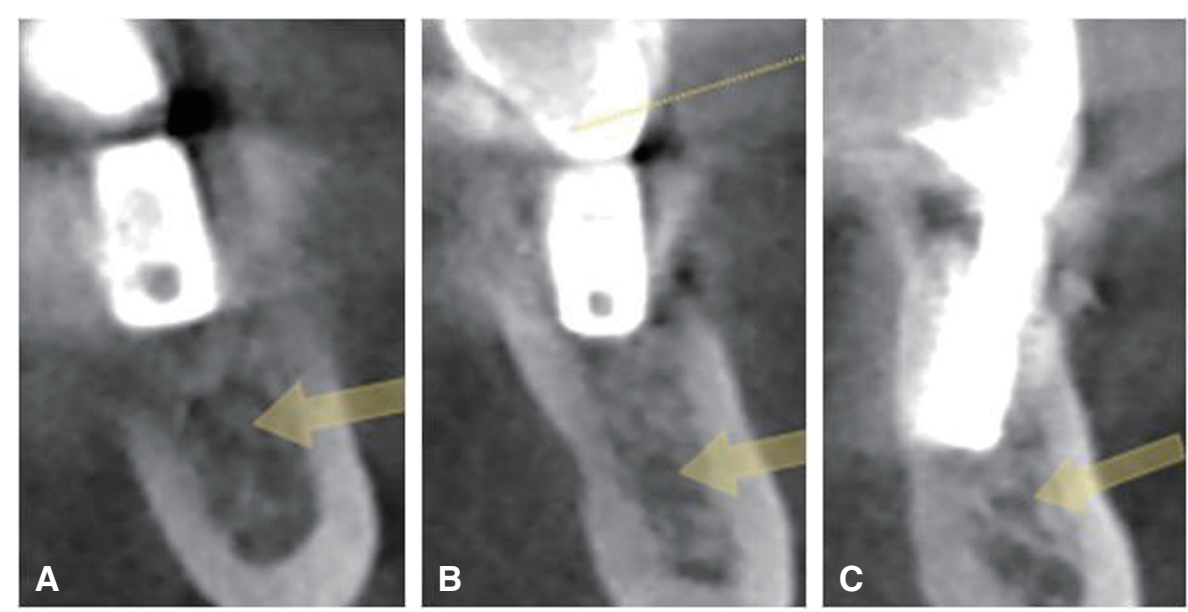

Fig. 6. Dental CBCT coronal views of \#47i (A), \#46i (B), \#44i (C). The arrows are pointing the mandibular canal. 
지각이상이 더 잘 생길 수 있는 환자 군은 여자, 고령, 과거 neuropathic pain 경험 및 치료, 과거 심한 두경부 통증 경험, 치료 전 통증을 느낀 병력이 긴(근관치료의 경우) 환자 등이다. ${ }^{9}$

신경 손상이 심하지 않은 경우 hyperesthesia가 주로 나타날 수 있고, 심한 경우 초기에는 anesthesia를 보이 다가 신경재생이 시작되면서 paresthesia를 나타낼 수 있다. 또한 초기에는 아프지 않다가 신경 재생과정에서 chronic neuroma가 형성되면서 통증이 생길 수 있다. 손 상 3 개월 뒤에는 영구적인 중심성, 말초성 손상이 생길 수 있으며 이런 경우 수술적 접근에도 반응이 없을 수 있다. 6 개월 이후에도 지속되는 손상의 경우 영구적 손 상으로 남을 수 있다. ${ }^{4}$

수술적 접근의 적응증은 시술 중 의심되는 신경 절단 을 관찰한 경우, 3 개월 이후에도 경감이 없는 이상감각, 신경종(neuroma)형성에 의한 통증, 하악관의 기형이나 이물질의 존재, 진행성의 지각이상 또는 통증증가의 경 우이다. 비적응증은 중심성 신경병증성 통증이 있거나 이상감각의 개선이 있거나 신경의 단순 타박상인 신경 실행증(Neuropraxia)이거나 감각이상증이 허용할 만한 수준일 경우(환자의 불편감이 크지 않은 경우), 대사성 신경병증이 있거나 전신질환을 가진 환자이거나 고령, 초기 외상 이후 장시간이 흐른 경우이다. ${ }^{9}$

모든 외과시술은 신경의 손상을 야기할 수 있다. ${ }^{10}$ 외 과시술 시 신경손상을 최소화하기 위해서는 기계적 손 상을 피하기 위한 해부학적 숙지는 기본이다. 또한 신경 과의 거리가 존재하더라도 과도한 압력은 신경을 손상 시킬 수 있다. ${ }^{4}$ 따라서 발치, 임플란트, 치주수술, 신경치 료, 하악 전달 마취 등을 시행 시에 기구 조작 및 첩약 시 에도 압력에 주의해야 한다. ${ }^{9}$ 또한 부종이나 출혈이 존 재시 하악관 같은 폐쇄된 공간에서는 신경에 심각한 손 상을 야기할 수 있으므로 출혈이나 부종의 적극적인 관 리를 위해 각각 경우에 따라 적절한 지혈제 또는 스테로 이드 등의 첩약이 필요하다. 화학적 손상을 줄이기 위해 서는 오염된 기구, 마취제, 첩약을 적용하지 않도록 주 기적인 관리가 필요할 것이다. 치과용 시술 시 임플란 트 드릴 또는 고속용 핸드피스의 사용으로 조직의 온도 가 고온으로 상승하는 경우 직접적인 신경 손상 및 이 차적인 염증 생성으로 인한 지연된 신경손상을 야기할 수 있다. ${ }^{11}$ 적절한 주수 및 속도 조절, 적용 시간 감소 등 을 통해 조직의 온도를 조절해야 한다. 시술 중 환자가 electrical pain을 호소하는 경우 신경의 손상 가능성을
염두에 두고 시술, 후 지속적인 관찰을 통해 지각이상 반응 발현 여부를 확인하여 조기 발견 및 신속한 처치를 가능하도록 해야 할 것이다. ${ }^{4}$

시술 후 마취가 풀리고 나면 환자의 지각이상 여부를 즉시 체크하는 것이 모든 외과적 시술 후에 반드시 필요 하다. 지각이상을 호소하는 경우 가능하다면 정량적 감 각기능 검사(quantitative sensory test)를 시행하고 이상 감각이 느껴지는 부위를 표시, 기록한다. 문제가 되는 임플란트나 이물질이 있다면 제거하고 고용량의 스테 로이드(Dexamethasone 4 - $6 \mathrm{mg}$ x3/day; 5 - 7일간 점 감함)를 10 - 14일간 처방한다. NSAIDs (nonsteroidal anti-inflammatory drugs)를 스테로이드와 병행 또는 대체 처방하여 약 3 주간 약물치료(스테로이드 복용량 감소위해)한다. 위장장애 예방을 위해 proton-pump inhibitors (PPIs)도 함께 처방한다. 만약 타는 듯한 통 증 등의 다른 종류의 통증이 존재하면 TCA (tricyclic antidepressant)/AED (antiepileptic drugs)를 처방한 다. ${ }^{12-14}$ 일주일 정도 후에 neurosensory examination을 시행하고 이전의 지각이상의 정도 부위와 비교한다. 지 각이상이 존재하면 처음 3 주간은 매주, 그 후 12 주간은 2 - 3주에 1번씩 neurosensory examination을 시행한다. 필요시 NSAIDs를 추가처방 할 수 있다. 12 주 후 또는 적응증일 경우 microneurosurgical treatment를 시행한 다. 환자에게는 심리적인 지지가 필수적이며 부가적인 물리치료도 시행될 수 있다. 12주 후에도 증상이 약물치 료에 의해 경감되고 있고 적응증인 경우 추가 처방할 수 있다. ${ }^{4}$

\section{결론}

본 연구에서는 치과시술 후 지각이상이 나타난 세 증 례를 고찰하였다. 이를 통해 치과 시술시 지각이상의 위 험군을 판단하고, 시술시의 위험성을 감소시키고 지각 이상 발생시 적절한 처치를 통하여 손상을 최소화하여 관리하는 방법에 대한 숙지를 통해 환자의 불편감을 예 방하고 감소시키는 노력이 필요함을 강조하고자 하였 다.

\section{Acknowledgments}

본 연구는 2015년도 부산대학교치과병원 임상연구비 지원으로 이루어졌음. 


\section{References}

1. Merskey HE. Classification of chronic pain: descriptions of chronic pain syndromes and definitions of pain terms. Prepared by the International Association for the Study of Pain, Subcommittee on Taxonomy. Pain Suppl 1986;3:S1-226.

2. Sunderland S. A classification of peripheral nerve injuries producing loss of function. Brain 1951;74: 491-516.

3. Seddon HJ. Three types of nerve injury. Brain 1943;66:247-88.

4. Juodzbalys G, Wang HL, Sabalys G. Injury of the inferior alveolar nerve during implant placement: a literature review. J Oral Maxillofac Res 2011;2:e1.

5. Abarca M, van Steenberghe D, Malevez C, De Ridder J, Jacobs R. Neurosensory disturbances after immediate loading of implants in the anterior mandible: an initial questionnaire approach followed by a psychophysical assessment. Clin Oral Investig 2006;10:269-77.

6. Benoliel R, Sharav Y. Chronic orofacial pain. Curr Pain Headache Rep 2010;14:33-40.

7. Yoon JA, Kang JK, Ahn HJ, Choi JH, Kim CY. A study on types and counterplans of medical accident experienced by dentists in Seoul(2004). J Oral
Med Pain 2005;30:163-200.

8. Han SR, Yeo SP, Lee MK, Bae YC, Ahn DK. Early dexamethasone relieves trigeminal neuropathic pain. 2010;89:915-20.

9. Alves FR, Coutinho MS, Gonçalves LS. Endodontic-related facial paresthesia: systematic review. J Can Dent Assoc 2014;80:e13.

10. Libersa P, Savignat M, Tonnel A. Neurosensory disturbances of the inferior alveolar nerve: a retrospective study of complaints in a 10-year period. J Oral Maxillofac Surg 2007;65:1486-9.

11. Peñarrocha Diago M, Boronat López A, Lamas Pelayo J. Update in dental implant periapical surgery. Med Oral Patol Oral Cir Bucal 2006;11:E42932.

12. Galloway EB 3rd, Jensen RL, Dailey AT, Thompson BG, Shelton C. Role of topical steroids in reducing dysfunction after nerve injury. Laryngoscope 2000;110:1907-10.

13. Jancsó G, Kiraly E, Jancsó-Gábor A. Pharmacologically induced selective degeneration of chemosensitive primary sensory neurones. Nature 1977;270: 741-3.

14. Kohnelein KE, Ocker K, Seitz HD. Experimental rails to inhibit neuroma formation. Chir Plast (Berl) 1980;5:207-11. 


\section{치과 시술 후 나타난 신경손상의 관리}

\section{정성희 ${ }^{1,2}$, 이선희 ${ }^{1,2}$, 안용우 ${ }^{1,2}$, 허준영 $^{2}$, 전혜미 ${ }^{3}$, 옥수민 ${ }^{1,2 *}$}

${ }^{1}$ 부산대학교 치의학전문대학원 구강내과학교실

${ }^{2}$ 부산대학교치과병원 구강내과

${ }^{3}$ 부산대학교병원 구강내과

의원성의 외상 혹은 감염은 신경 손상의 중요한 원인 중 하나이며, 이는 의사-환자 관계에 매우 큰 영향을 주는 일로 여 겨진다. 관련 치과 술식의 예로는 임플란트 시술시 직접적인 혹은 열에 의한 손상, 근관치료시의 약제 유출, 발치시의 외력, 전달국소마취시 바늘에 의한 외상, 악골 수술로 인한 외상 등이 있다. 이러한 신경손상이 발생하지 않도록 위험 군 예측 및 시술 시 주의가 필요하며, 신경 손상 시 조기 발견을 통해 제대로 대처하지 않으면 만성적 신경병증으로 발 전할 수 있는 가능성이 높아질 수 있으므로 그 징후를 신속히 파악하고 적절히 관리하는 것이 매우 중요하다.

(구강회복응용과학지 2016;32(2):123-9)

주요어: 신경손상; 의원성 손상

*교신저자: 옥수민

(50612)경남 양산시 물금읍 금오로 20 부산대학교 치의학전문대학원 구강내과학교실

Tel: 055-360-5243 | Fax: 055-360-5238 | E-mail: oksoomin@pusan.ac. kr

접수일: 2016년 4월 28일 | 수정일: 2016년 6월 10일 | 채택일: 2016년 6월 13일 